\title{
Proceedings of 2014 Stillbirth Summit
}

\author{
Lindsey Wimmer \\ From Stillbirth Summit 2014 \\ Medina, MN, USA. 19-21 June 2014
}

Stillbirth is a devastating pregnancy outcome that occurs once in every 160 pregnancies in the United States, [1] with similar rates in other developed nations around the world. Despite advances in medical knowledge and technology, there have been slow trends in stillbirth reduction in most high income countries over the past two decades relative to other declines in infant mortality [2]. Contributing to this lack of progress is the minimal amount of research activities dedicated to stillbirth etiologies and prevention methods.

As a follow-up to Stillbirth Summit 2011, Star Legacy Foundation hosted Stillbirth Summit 2014 in Minneapolis, MN (USA) June 19-21, 2014. The goals of the summit were to support current and emerging stillbirth research, promote collaboration among interested parties, and to encourage dialogue regarding the complex factors affecting stillbirth incidence and care. In attendance were researchers, health care professionals, stillbirth advocates, and bereaved families. The following oral papers offer an overview of the research presented and discussed at this event.

Published: 15 April 2015

\section{References}

1. MacDorman MF, Kirmeyer S: Fetal and perinatal mortality, United States, 2005. National Vital Statistics Report 2009, 57(8):1-19.

2. Lawn JE, Blencowe H, Pattinson R, Cousens S, Kumar R, Ibiebele I, Gardosi J, Day LT, Stanton C, Lancet's Stillbirths Series steering committee: Stillbirths: Where? When? Why? How to make the data count? Lancet 2011, 377(9775):1448-63.

Submit your next manuscript to BioMed Central and take full advantage of:

- Convenient online submission

- Thorough peer review

- No space constraints or color figure charges

- Immediate publication on acceptance

- Inclusion in PubMed, CAS, Scopus and Google Scholar

- Research which is freely available for redistribution

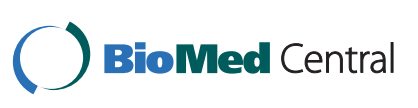

(c) 2015 Wimmer; licensee BioMed Central Ltd. This is an Open Access article distributed under the terms of the Creative Commons Attribution License (http://creativecommons.org/licenses/by/4.0), which permits unrestricted use, distribution, and reproduction in any medium, provided the original work is properly cited. The Creative Commons Public Domain Dedication waiver (http:// creativecommons.org/publicdomain/zero/1.0/) applies to the data made available in this article, unless otherwise stated. 